\title{
Social Media Marketing Strategy Applied to Oral Hygiene
}

\author{
Estrategia de Marketing Social Aplicado a Higiene Dental
}

\author{
Brenda Yuliana Herrera Serna; Olga Patricia López Soto \& Oscar Williamson Londoño
}

HERRERA, S. B. Y.; LÓPEZ, S. O. P. \& WILLIAMSON, L. O. Social media marketing strategy applied to oral hygiene. Int. J. Odontostomat., 11(3):279-285, 2017.

\begin{abstract}
This project aims to apply psychological strategies based on social media marketing in order to set an oral hygiene habit in school-aged children to prevent dental caries in the long term. This is a descriptive study that assessed the recall of an oral hygiene campaign based on social media marketing of 34 school-aged children, 24 months after the end of the campaign. The instrument allowed the assessment of the advertising campaign, according to different levels of recall. The findings were confirmed with oral health epidemiological indices. Most of the school-aged children recalled "brushing teeth" as the campaign message and all of them expressed interest in the campaign to be repeated. Plaque index and brushing technique suggested that the school-aged children group has a good level of dental plaque removal after 24 months after the end of the social media marketing campaign. The required behavioral modification demands changes both at micro (individual) level and at macro levels of the organizations, in a short and a long term, as well as the participation of all actors involved in establishing healthy oral habits as a norm in the society. This study contributes to the transformative potential of social media marketing by understanding habits formation such as interaction among different stimuli within a favorable context.
\end{abstract}

KEY WORDS: social marketing, evaluation, oral health.

\section{INTRODUCTION}

Although clinical evidence shows that mechanical oral hygiene is essential to prevent and control caries and periodontal disease, most individuals do not properly perform this process. This may be due to lack of motivation, lack of skill or both (Maltz et al., 2010). Oral hygiene processes need a long-term commitment and a constant support throughout different stages of life cycle. These stages determine behavioral changes related to age, changes in economic status and other variables responsible for individual health. However, oral hygiene regarded as a "usual" practice or a "habit" is always decisive. Clinical evidence shows that bacterial plaque and its metabolism play an important role in dental caries development. Mechanical plaque control interrupts dental biofilm formation and causes biofilm composition compatibility with oral health in most patients. Natural cleaning methods (tongue, cheeks, and salivary flow movements) become ineffective, thus mechanical methods depict an underlying way to monitor dental biofilm effectiveness (van der Weijden \& Slot, 2011). These methods should be performed since childhood, so that individuals acquire them as true "habits".
The habit is understood as an automatic response characterized by some behavioral aspects within the context (environmental aspects or previous actions). It is acquired through repetition processes that gradually establish cognitive processes in the procedural memory. Forty-five percent of daily behaviors tend to be repeated in the same place almost every day (Wood, 2002). Many behavioral sequences of a person are repeatedly performed in similar contexts. When responses and context characteristics take place simultaneously, a potential association occurs between them, thus the context comprises the response. This co-activation records direct links in the memory. Action training within the context (e.g. brushing teeth) should be a motivating goal (e.g. receiving a stimulus after brushing teeth), but once the link between context and action is set, the answer arises without activating a specific goal.

The evidence regarding neural functioning suggests that through repetition, all integrated responses are stored in the memory including the context where they take place (Barnes et al., 2005) 
(e.g. finish eating suggests the action of brushing teeth). Integrated responses are referred and performed as a unit, which agrees with the idea that a habit requires conscious control to be completed. There is a theory that states that during human practice, actions intentions, attitudes and decisions are involved. Verplanken \& Wood (2005) suggest that the strategies for setting positive habits must be implemented as a natural and easy change within the context (e.g. tooth brush and toothpaste should be provided to increase brushing teeth at school) or through structural changes to foster desired behaviors (e.g to provide a comfortable and a nice environment to brush teeth at school and to give time to do it after the break).

This project aims at applying psychological strategies based on social marketing for setting the habit of oral hygiene in school-aged children as a way to prevent dental caries in the long term. It is possible to advance in the control and prevention of this important public health condition worldwide through a proven strategy as the one proposed by this study. There have been educational interventions regarding oral health of children, however, sustaining them through time, and using other strategies that are not focused on creating habits have limited the results in long-term results.

\section{MATERIAL AND METHOD}

This descriptive study was used to assess a recall of an oral hygiene campaign based on social marketing. The instrument was designed by following the recommendations for assessing an advertising campaign, taking into account different levels of recall. (Treviño, 2000; Carvajal, 2014). The participation of school-aged children was ruled by the ethical standards set in the 8430 standard, 1993 of the Ministry of Health, Republic of Colombia. The corresponding Bioethical authorization was requested to the Bioethics Committee of the University where the study was conducted.

Preventive oral health campaign was conducted throughout the entire 2012 school year, with an initial participation of 80 school-aged children, boys and girls. This campaign included the initial condition of oral health and dental plaque index of school-aged children, an educational session on the importance and the way to perform oral self-care for both parents and teachers and an educational session on dental self-care for school-aged children. These activities aimed to foster and train participants in the "Bass" technique as suggested by the American Dental Association. Two practical workshops on brushing techniques were held in order to ensure an adequate training and to appoint oral health leaders from the group of school-aged children. They were in charge of collaborating with researchers on daily brushing sessions at school, one daily brushing and the application of the daily "marketing" strategy.

The marketing strategy was based on the principles proposed by the economist Leal Jiménez, who is a researcher in social media marketing (Leal, 2000). The main elements of the strategy used to guide the school-aged children to reach the desired behavior of setting the habit of daily oral hygiene were developed according to the following aspects: Activities directly related to social marketing to increase positive perceived benefits of behavior (Ajzen, 1991). Thus, concepts such as "beautiful teeth", "pretty smile", "fresh breath" were considered as positive results, and as added benefits such as rewards as follows: a. Material rewards with no relation (Kunreuther et al., 1985). School-aged children were exposed to present information and skills training to lead them to reach the change, particularly, on daily brushing practice to control dental plaque. This reward was linked to an ecological campaign that searched to raise awareness on domestic endangered animals care. This reward had two concepts: daily reward for the complying with the habit and weekly reward for uninterrupted repetition of oral dental care. The child received an empty album to stick the clues collected every day and the pictures of animals. For daily brushing, the child received a daily puzzle phrase with the characteristics of the animals. Upon completion of weekly activities, students could get a three-dimensional puzzle of a 3D animal. Each Monday, school-aged children who brushed their teeth at home could get a photo of the animal of the week for their album. Each child collected a total number of 16 animals, which were exhibited on an animal mobile at the end of the campaign. $\mathbf{b}$. Materials rewards related (Perry et al., 1990). Each kid received a couple of toothbrushes, one for home and the other one for school. Moreover, toothbrushes were replaced at least every six months. c. Related services (Wood). Each child had fluoride applications as a preventive protection measure.

The second marketing strategy aimed to reduce the perceived negative results of the behavior (Rosenstock, 1990). In this case, the purpose was to 
diminish the feeling of obligation to comply with a duty or behavior as a response to authority. As a strategy, each child was appointed to be a leader in oral health and got the corresponding label for some days. There was not a school authority to control daily brushing. A second negative result was considering tooth brushing as a not highly fun. In this regard, two groups competed for being the best group that complied with the action of imitating the leader and received the reward for performing the action. The third phase of the strategy was to increase pressure on the influencing groups of the social environment of the school to achieve the desired behavior (Barnes et al.). The strategy implemented to comply with this issue was that parents designed toothbrush cases at school time; they worked with the kids in the project. The fourth phase aimed to increase the sense of self-efficacy of the school-aged children in relation to behavior (Wilkie, 1990). Schoolaged children were encouraged to move ahead towards the behavior phase creating the feeling that they could actually perform the behavior as follows: internal effectiveness was guaranteed by providing proper information to people involved in it, and by training on the brushing technique to develop the necessary skills for making the habit of brushing teeth something simple under the concept "what is learned becomes elemental". External effectiveness was used to make school-aged children recognize the action of brushing as something that they could do. School-aged children were given a toothbrush, toothpaste, a place to put them (handmade toothbrush cases), a school place to perform the action, a leader to guide them and a permanent trainer (provided by the University). The fifth phase included the implementation of social learning theory, according to this theory people tend to practice behaviors and want to be rewarded for their efforts in order to commit to a task. This direct learning included three components: sequential approach: motivation strategy and brushing practices led school-aged children to gradually adapt to the new behavior. This was achieved by combining the action of group brushing, with recreational activities, contests and rewards. Repetition: daily tooth brushing contributed for a better chance to do it well and for making it as a permanent behavioral activity. Effort: Concrete and reachable goals such as tooth brushing and rewards for the effort were set to achieve high levels of behavioral self-control. Strategies for passing the behavior (Graeff et al., 1993): a- Making the impossible possible: Daily brushing was possible because the necessary implements were available within the school environment. b. Making the complicated simple: The objective was to brush teeth daily, this technique would be later implemented. The habit is set forever. The marketing strategy also included the problem of time control: There was a school time for this activity and also the need for greater urgency: As each child complied with brushing their teeth, each one received the reward. It was important to have the album full, and the 3D animal mobile done, and to avoid forgetfulness: reminders of oral hygiene habit were placed on the classroom walls, in the school social places, in the bathroom mirror and similar places.

Thirty-four school-aged children out of 80 , who initially participated in the campaign, were surveyed. The survey included sociodemographic variables, recall activities related to social media marketing, assessment of the activities and two epidemiologic indices: percentage of dental plaque and tooth surfaces brushed. A calibrated examiner (Kappa: 0.85), expert in taking epidemiological indices, took the indices. Descriptive analyses of central tendency for quantitative variables and analysis for qualitative proportions were done by using the SPSSS program version 21.

\section{RESULTS}

Thirty-four school-aged children who participated in the oral program based on the social marketing strategy completed the survey and the clinical examination. They were still living in the same town where the project had been conducted. Sixty-one point eight percent of these children were female and 38.2 $\%$ of them were male. The survey population was distributed by age as follows: $32.4 \%-11$ years old, $32.4 \%$ - 12 years old, and $35.3 \%$ - 13 years old.

The highest percentage of children recalled the 3D animal mobile and identified "brushing teeth" as the campaign message. All of them expressed their will to repeat the campaign, and assessed most of the activities as fun. The prize of the campaign was to receive toothbrushes and they reported having learned how to brush their teeth. They stated to remember some images used in the campaign while brushing teeth (Table I).

More than $50 \%$ of the school-aged children assessed the following activities as excellent: opening party, sports day, closing party, animal mobiles, puppets shows, and film. Table II shows those activities in the same order. 
Table I. Survey Results of the recall campaign on Oral Health

\begin{tabular}{|c|c|c|}
\hline Activity & $\mathbf{N}$ & $\%$ \\
\hline Opening party & 2 & 5.9 \\
\hline Animal mobiles & 8 & 23.5 \\
\hline Frieze & 1 & 2.9 \\
\hline Children's film & 4 & 11.8 \\
\hline Puppet's show & 3 & 8.8 \\
\hline Closing party & 5 & 14.7 \\
\hline Sport's day & 10 & 29.4 \\
\hline "Concentration" Game & 1 & 2.9 \\
\hline \multicolumn{3}{|c|}{ What was the message of the campaign on oral health? } \\
\hline Care of forests' animals & 5 & 14.7 \\
\hline Toothbrush & 29 & 85.3 \\
\hline Other & 0 & 0 \\
\hline \multicolumn{3}{|c|}{ Would you like to have this campaign on oral health again? } \\
\hline Yes & 34 & 100 \\
\hline No & 0 & 0 \\
\hline \multicolumn{3}{|c|}{ What do you think of the group activities? } \\
\hline Nice & 8 & 23.5 \\
\hline Fun & 26 & 76.5 \\
\hline Other & 0 & 0 \\
\hline \multicolumn{3}{|c|}{ What were the rewards of the campaign? } \\
\hline Games & 3 & 8.8 \\
\hline Toothbrushes & 18 & 52.9 \\
\hline Animals assembly games & 10 & 29.4 \\
\hline Closing party & 2 & 5.9 \\
\hline \multicolumn{3}{|c|}{ How much did you like the campaign on oral health? } \\
\hline Very much & 30 & 88.2 \\
\hline Acceptable & 4 & 8.8 \\
\hline \multicolumn{3}{|c|}{ What didn't you like of the campaign on oral health? } \\
\hline Assembling of animals & 3 & 8.8 \\
\hline Teeth check up & 3 & 8.8 \\
\hline I liked every thing & 28 & 82.4 \\
\hline \multicolumn{3}{|c|}{ What did you learn with the campaign on oral health? } \\
\hline How to assembly the animals & 7 & 20.6 \\
\hline How and why to brush my teeth & 25 & 73.5 \\
\hline What animals we need to take care of & 2 & 5.9 \\
\hline \multicolumn{3}{|c|}{$\begin{array}{l}\text { When you brush your teeth, do you remember something of the } \\
\text { campaign? }\end{array}$} \\
\hline Animals of the mobiles & 13 & 38.2 \\
\hline Images of the expectative campaign & 21 & 61.8 \\
\hline
\end{tabular}

Table II. Assessment of activities by 34 school-aged children who participated in the campaign on oral health base on "Social media Marketing".

\begin{tabular}{lllllllllll}
\hline Assessment & Excellent & \multicolumn{2}{c}{ Good } & \multicolumn{3}{c}{ Average } & \multicolumn{2}{c}{ Bad } & \multicolumn{2}{c}{$\begin{array}{c}\text { Do not } \\
\text { remember } \\
\end{array}$} \\
& $\mathrm{n}$ & $\%$ & $\mathrm{n}$ & $\%$ & $\mathrm{n}$ & $\%$ & $\mathrm{n}$ & $\%$ & $\mathrm{n}$ & $\%$ \\
\hline Opening party & 24 & 70 & 5 & 14.7 & 2 & 5.9 & 0 & 0 & 2 & 5.9 \\
Healthy Bowling game & 7 & 20.6 & 11 & 32.4 & 4 & 11.8 & 1 & 2.9 & 11 & 32.4 \\
Animal mobiles & 19 & 55.9 & 13 & 38.2 & 1 & 2.9 & 0 & 0 & 1 & 2.9 \\
Frieze & 14 & 41.2 & 12 & 35.3 & 2 & 5.9 & 1 & 2.9 & 5 & 14.7 \\
Children's film & 19 & 55.9 & 9 & 26.5 & 1 & 2.9 & 0 & 0 & 5 & 14.7 \\
Puppets shows & 19 & 55.9 & 9 & 26.5 & 1 & 2.9 & 0 & 0 & 5 & 14.7 \\
Closing party & 22 & 64.7 & 6 & 17.6 & 0 & 0 & 1 & 2.9 & 5 & 14.7 \\
Sports day & 23 & 67.6 & 6 & 17.6 & 0 & 0 & 0 & 0 & 5 & 14.7 \\
Story telling shows & 16 & 47.1 & 5 & 14.7 & 3 & 8.8 & 0 & 0 & 10 & 29.4 \\
"Concentration" Game & 12 & 35.3 & 12 & 35.3 & 0 & 0 & 1 & 2.9 & 9 & 26.5 \\
\hline
\end{tabular}


HERRERA, S. B. Y.; LÓPEZ, S. O. P. \& WILLIAMSON, L. O. Social media marketing strategy applied to oral hygiene. Int. J. Odontostomat., 11(3):279-285, 2017.

Table III. Statistical brushing and dental plaque indices of 34 school-aged children.

\begin{tabular}{lccc}
\hline & Average & $\mathrm{Cl} 95 \%$ & Standard Deviation \\
\hline Brushing index & 77 & $70.64-83.54$ & 18.48 \\
Dental plaque index & 0.45 & $0.28-0.62$ & 0.48 \\
\hline
\end{tabular}

Brushing index averaged $77 \%$ of tooth surfaces brushed, confidence interval (Cl) $95 \%$ of minimum $71 \%$ of surfaces. This index is considered efficient above $70 \%$. The plaque index averaged 0.45 $\%$, which corresponds to $15 \%$ of plaque in the mouth, with $\mathrm{Cl}$ of $95 \%$ that indicated a top of $20 \%$ more plaque (Table III).

\section{DISCUSSION}

Social media marketing campaigns are increasing their use as a way to reach the target public to change health behaviors or to promote prosocial and health topics such as oral health. It is important to understand the extent of a meaningful impact on the population. This is done to characterize the most effective and efficient delivery of messages to groups, and to assess the overall strengths and weaknesses of social media marketing interventions to improve health (Corrigan, 2012).

This study demonstrates that it is possible to direct a campaign for a certain behavior supported by rigorous theory to generate habits. Similarly, the study of Fools speed assessment in England shows that it is possible to design advertising campaigns explicitly supported by proven theoretical constructions (Stead et al., 2005).

In this sense, this advertising campaign shows favorable results about the main message to be transmitted. The campaign awareness was consistently associated with better attitudes and expected behaviors. This is demonstrated when brushing teeth is associated with images of the campaign making it more accepted by school-aged children. This level of consciousness associated with knowledge, attitude and behavior has been considered a successful factor in social media marketing campaigns (Lacko-Evans et al., 2013).

The fact that the best assessed activities by school-aged children were those performed in groups confirms that social interaction is one of the most effective strategies to improve group relationships (Corrigan et al., 2012) and the benefits of such social interaction were probably the ones that increased the effects of the campaign. About features of competitiveness among peers and the feeling of mastery actions, Novoa Ramírez (2014) states that children are more likely to be manipulated by advertising, which creates in them fictitious needs. The main motivation on the behavior of children is thedesire of competition, rivalry (which normally exist between them) and the feeling of belonging to a group, familiarity and identification with the advertised object presented to them with certain frequency.

The extent of acceptance by school-aged children regarding the activities of the campaign and their correspondence with the levels of dental plaque removal, as a measure of expected behavior, plays an important role in the incorporation of habits in children and youngsters. A social change campaign as a planned and directed effort by a group of agents of change who try to persuade a target population to accept, modify or abandon certain ideas, attitudes, practices and behaviors may modify habits positively, as suggested by Curiel Lorenzo (2012) who promotes the use of a media library among school children in Cuba.

Besides, social media marketing programs that apply active measures lead to great changes consistent with the identification of the message, "brushing teeth" in this case, monitoring the rate of plaque, that is demonstrated by studies that sought changes in beliefs and attitudes for extending the "culture of prevention" with respect to undesirable behaviors in school-aged children (Bruce \& McGrath, 2005).

These results agree with those reported in other studies that also showed positive effects on children and teenagers attitudes and practices after leading educational campaigns (Bruce \& McGrath) and they also support the assertion of some authors about the fact that prevention programs implemented in school are one of the main resources to strive some problems related to the health of school-aged children (Mello et al., 2007). 
Age has also proven to be an important issue to be considered when implementing such campaigns. The optimal age for interventions seems to be between 9 and 10. At this age, children show better results of recalling and appropriation. This can be explained from the perspective that individuals are less prone to be easily influenced through the years (Calero García et al., 2008).

However, it is evident that implementing a strategy is an important step to reduce oral problems, but it is not enough because changing a behavior requires changes at a micro level (individual) of the organizations and at a macro level over the short and long term as well as the participation of all actors who promote healthy oral habits as a social norm. Similar findings can be observed in campaigns dealing with childhood obesity (Thomas et al., 2014).

\section{CONCLUSIONS}

Dental caries is an identified public health problem and its solution requires the development of interventions from holistic and multidimensional perspectives supported by intersectoral agents and multidisciplinary work groups that consider children's health as a priority. There is a warning voice to strengthen areas such as social marketing that aims for long-term impacts in a comprehensive evaluation of health interventions. This is demonstrated by the results of this study in which the largest percentage of schoolaged children recalled the $3 \mathrm{D}$ animal mobile, identified "brushing teeth" as a campaign message, reported willingness to repeat the campaign and assessed most of the activities as fun. More than $50 \%$ of the schoolaged children rated the opening party, sports day, closing party, animal mobiles, puppets show, and the movie, in that order, as excellent activities. The rate of dental plaque and brushing technique suggested that the group of school-aged children surveyed has a good level of dental plaque removal after 24 months of having finished the social marketing campaign.

As health is considered a structural and transversal aspect of everybody's life, every discipline can also contribute to search and guarantee better conditions for society and school age is key to its development.

Further deep research is needed in order to understand how to optimize resources, create synergies across multiple interventions and understand possible ways to integrate initiatives that lead changes from an individual behavioral level towards a community level.

HERRERA, S. B. Y.; LÓPEZ, S. O. P. \& WILLIAMSON, L. O. Estrategia de marketing social aplicado a higiene dental. Int. J. Odontostomat., 11(3):279-285, 2017.

RESUMEN: Este proyecto tiene como objetivo aplicar estrategias sicológicas basadas en el marketing social para la fijación del hábito de la higiene oral en escolares como medida de prevención de la caries dental a largo término. Se trata de un estudio descriptivo el cual se utilizó para evaluar el recordatorio de una campaña de higiene oral fundamentada en el marketing social en 34 escolares tras 24 meses de la campaña original. El instrumento permitió la evaluación de la campaña publicitaria, según los diferentes niveles de recuerdo, y los hallazgos fueron corroborados con índices epidemiológicos de salud oral. El mayor porcentaje de escolares recordó el mensaje de la campaña "cepillarse los dientes", todos manifestaron querer que la campaña se repitiera. El índice de placa dental y de cepillado indicó que el grupo de escolares encuestados tiene un buen nivel de remoción de placa dental, después de 24 meses de haber terminado la campaña de marketing social. Implicaciones sociales: la modificación requerida de comportamiento, demanda cambios tanto a nivel micro (individuo), de las organizaciones y a nivel macro tanto a corto como a largo plazo; así como la participación de todos los actores involucrados en lograr que los hábitos orales saludables se conviertan en una norma en la sociedad. Originalidad/valor: este estudio contribuye al potencial de transformación del marketing social ubicando la generación de hábitos como la interacción entre diferentes estímulos dentro de un contexto favorable.

PALABRAS CLAVE: marketing social, impacto en salud, salud oral.

\section{REFERENCES}

Ajzen, I. The theory of planned behavior. Organ. Behav. Hum. Decis. Process., 50(2):179-211, 1991

Barnes, T. D.; Kubota, Y.; Hu, D.; Jin, D. Z. \& Graybiel, A. M. Activity of striatal neurons reflects dynamic encoding and recoding of procedural memories. Nature, 437(7062):1158-61, 2005.

Bruce, B. \& McGrath, P. Group interventions for the prevention of injuries in young children: a systematic review. Inj. Prev., 11(3):143-7, 2005.

Calero García, M. D.; Vives Montero, M. C.; García Martín, M. B.; Soriano Serrano, M.; Calero García, M. \& Berral García, E. Impacto de una campaña escolar de prevención de riesgos. Rev. Psicol. Trab. Organ., 24(2):169-86, 2008.

Carvajal, H. Modelo de Encuesta para evaluar una campaña publicitaria - PostTest Publicitario. Sitio Web, Investigación de nichos de mercado, 2014. Disponible en: https:// modelodeencuesta.wordpress.com/2010/11/24/modelo-de-en- 
cuesta-para-evaluar-una-campana-publicitaria-\%E2\%80\%93posttest-publicitario

Corrigan, P. W. Where is the evidence supporting public service announcements to eliminate mental illness stigma? Psychiatr. Serv., 63(1):79-82, 2012.

Corrigan, P. W.; Morris, S. B.; Michaels, P. J.; Rafacz, J. D. \& Rüsch, $\mathrm{N}$. Challenging the public stigma of mental illness: a meta-analysis of outcome studies. Psychiatr. Serv., 63(10):963-73, 2012.

Curiel Lorenzo, S. Elementos de una campaña de marketing social para la promoción de la Mediateca municipal de Soyo, Angola. Rev. Arquit. Ing., 6(3):1-8, 2012.

Graeff, J. A.; Elder, P. \& Booth, E. M. Communication for Health and Behavior Change. A Develop Country Perspective. San Francisco, Jossey-Bass Publishers, 1993.

Kunreuther, H.; Sanderson, W. \& Vetschera, R. A behavioral model of the adoption of protective activities. J. Econ. Behav. Organ., $6(1): 1-15,1985$

Lacko-Evans, S.; Malcolm, E.; West, K.; Rose, D.; London, J.; Rüsch, N.; Little, K.; Henderson, C. \& Thornicroft, G. Influence of Time to Change's social marketing interventions on stigma in England 2009-2011. Br. J. Psychiatry Suppl., 55:s77-88, 2013.

Leal, J. A. Gestión del Marketing Social. Madrid, McGraw-Hill, 2000. pp.208.

Maltz, M.; Jardim, J. J. \& Alves, L. S. Health promotion and dental caries. Braz. Oral Res., 24 Suppl. 1:18-25, 2010.

Mello, M. J.; Getz, M. A.; Lapidus, G.; Moss, J. \& Soulos, P. Innovations in injury prevention education. J. Trauma, 63(3 Suppl.):S7-9, 2007.

Novoa Ramírez, E. Globalización de la industria cultural del entretenimiento y su impacto en la publicidad para niños. Converg. Cient., 1(1):10-6, 2014.

Perry, C. L.; Baranowisky, T. \& Parcel, G. How Individuals, Environments, and Health Behavior Interact: Social Learning Theory. In: Glanz, K.; Lewis, F. M. \& Timer, B. (Eds.). Health Behavior and Health Education: Theory, Research, and Practice. San Francisco, Jossey-Bass, 1990.

Rosenstock, I. The Health Belief Model: Explaining Health Behavior Through Expectancies. In: Glanz, K.; Lewis, F. M. \& Timer, B. (Eds.). Health Behavior and Health Education: Theory, Research, and Practice. San Francisco, Jossey-Bass, 1990.

Stead, M.; Tagg, S.; MacKintosh, A. M. \& Eadie, D. Development and evaluation of a mass media Theory of Planned Behaviour intervention to reduce speeding. Health Educ. Res., 20(1):3650, 2005.

Thomas, S. L.; Olds, T.; Pettigrew, S.; Yeatman, H.; Hyde, J. \& Dragovic, C. Parent and child interactions with two contrasting anti-obesity advertising campaigns: a qualitative analysis. B. M. C. Public Health, 14:151, 2014.

Treviño, R. Publicidad: Comunicación Integral en Marketing. Ciudad de México, McGraw-Hill, 2000.

van der Weijden, F. \& Slot, D. E. Oral hygiene in the prevention of periodontal diseases: the evidence. Periodontol. 2000, 55(1):10423, 2011

Verplanken, B. \& Wood, W. Breaking and creating habits: Consequences for public policy interventions. J. Public Policy Mark., 25:90-103, 2005.

Wilkie, W. L. Consumer Behavior. $2^{\text {nd }}$ ed. New York, Wiley, 1990.

Wood, W.; Quinn, J. M. \& Kashy, D. A. Habits in everyday life: thought, emotion, and action. J. Pers. Soc. Psychol., 83(6):1281-97, 2002.

\author{
Corresponding author: \\ Brenda Herrera \\ Departamento de salud oral \\ Universidad Autónoma de Manizales \\ Manizales \\ COLOMBIA
}

E-mail: bherrera@autonoma.edu.co

Recibido : 26-04-2017

Aceptado: 30-06-2017 